دورية علمية محكمة كلية الآداب- جامعة أسوان أبريل 9 ب ب

\title{
"ALASTOR" AND SHELLEY'S LONGER POEMS: A NEW TRANSLATION AND NEW INTERPRETATION
}

\author{
By \\ Shaimaa Adham Basheer \\ Lecturer in English Literature \\ Qena Faculty of Arts
}

South Valley University 


\section{دورية علمية محكمةـ كلية الآداب- جامعة أسوان أبريل 9 ب ب}

قصيدة "ألاستر" وقصائد شيلي الطويلة: ترجمة جليدة و تفسير جديد شيماء أدهم بشير مدرس الأدب الانجليزي - قسم اللغة الانجليزية -كلية الآداب جامعة بنيز جنوب الو ادي بقنا

ملخص:

كونه أكثر شاعر نرجمت أثعاره الي العربية بعد شكسبير، يشغل "شيلي" مكانة

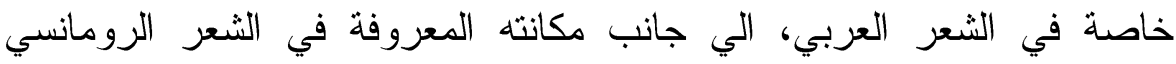

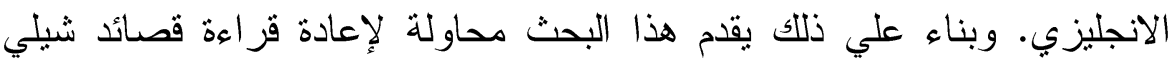
الطويلة من الشعر القصصي. وهي قصائد لم تلقي الاهنمام الكافي في الترجمة أو الدر اسة كما قدرت قصائده الغنائية القصيرة الثهيرة. وتقوم هذه الدراسة علي ترجمة "عناني" لقصيدتي "Queen Mab" and "Alastor" و التي فتحت الباب لإعادة صياغة رؤية لهذه القصائد الطويلة، وبالتالي إعادة فهم لجزء مغمور من حياة "شيلي" الأدبية، كان له أكبر تأثير علي تكوينه لاحقا. وهذه القصائد القصصية الطويلة كان لها أكبر أثز علي شعراء المدرسة الرومانسية العربية

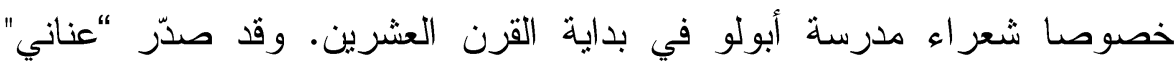
لتزجمته بمقدمة عن حباة الثاعر الشخصية و الأدبية والتي كان لها تأثير كبير في كتاباته الأولي. يبدأ البحث بمقدمة عن المدرسة الرومانسية الانجليزية ومكانة شيلي في هذه المدرسة، ويلي ذلك عرض للمدرسة الرومانسية العربية و أهم شعر ائها من مدرسة ابولو ، واللذين كان ل شعر "شيلي" وفلسفته أكبر تأثير عليهم حيث نو افقت أحلامهم و منظورهم للشعر الحديث الغير تقليدي مع رؤية شيلي التجديدية في كل من الشعر و الحياة. ويأني بعد ذلك تحليل وتقسير جديد لقصيدني "Queen Mab" and "Alastor" خلالها نأثر "شيلي" بالأساطير اليونانية القديمة و الجو الثرقي الساحر وفكره النقي وفلسفته العميقة في تلك المرحلة المبكرة من حياته. الكلمات المفتاحية: قصائد شيلي الطويلة، الثعر القصصي، "ألاستور"، ترجمة، 


\title{
"ALASTOR" AND SHELLEY'S LONGER POEMS: A NEW TRANSLATION AND NEW INTERPRETATION
}

\begin{abstract}
As the second English poet after Shakespeare whose works have most often been translated into Arabic, Shelley occupies a special place in Arabic poetry besides his own acknowledged stature among the English Romantic poets. The present research attempts to cast new light on Shelley's longer poems, which have received noticeably less appreciation than his popular mature short lyrics. This new interpretation is built on Enani's translation of "Queen Mab" and "Alastor", an expressive rendition that has opened up a fresh vision of the poet's longer works, providing insight into a hidden aspect of Shelley's literary path which dramatically influenced his artistic growth as he matured. Among those most affected by Shelley's longer poems were the Arabic Romantic poets, particularly the Apollo Group at the beginning of the twentieth century. Enani's Introduction to his translation included a biography of Shelley's personal life in order to highlight its role in shaping his early works. The research begins with an Introduction to the English Romantic era and Shelley's ranking among its poets. This is followed by an overview of the Arabic Romantic movement and its most notable poets from the Apollo Group, particularly due to their deep affinity with Shelley's works and attitude to life. (In fact, Shelley's innovative influence and lifestyle were instrumental in shaping the dreams and perspectives towards non-traditional poetry of these emerging young Arab poets.) The paper then provides a new analytical interpretation of "Queen Mab" and "Alastor" informed by Enani's translation, which reveals the influence of Greek mythology and Eastern mysticism, as well as the notion of purity, on the poet's works and philosophy of life during this early period.
\end{abstract}

Key Words: Shelley, Longer Narrative Poems, "Alastor", Translation, Interpretation. 


\section{Introduction}

There is no shortage of excellent Arabic translations of many of Shelley's mature works. Some of these include Prometheus Unbound by Louis Awad and Shelley's musical ballads by the Apollo Poet Society in the 1930s. There has been, however, a noticeable lack of attention by scholars, such as Gehane Raouf, to the poet's early verse in favor of his mature works, which had such a profound influence on Arab literature.

We typically read accounts of Shelley and his life rather than delve into his actual poetry. However, a full understanding of the poet's mature works, widely considered to have been created during an unexpected phase of creative energy, can only be gained by exploring his earliest offerings as well as the themes and ideals emerging in his poetry.

This present study benefits from Enani's translation of Shelley's early poetry, especially "Queen Mab" and "Alastor" to provide a new interpretation of Shelley's poetry in its early steps. The paper attempts to present the young, free, plain Shelley as he appears in his early narrative poems; poems that are immersed in idealism in a resistant search for oneself and the values of freedom for the human soul everywhere in the world.

These poems come narrative and long to give him space to discuss all about himself and discuss all his fears from start to finish. As the persona's in his poems go into a journey in a dreamy world, Shelley goes and takes the reader with him in the same journey hoping to find answers to all questions about God, faith, religion, and life. Influenced by Godwin, Shelley considered the reasoning mind a solution to all mankind's problems. This is because he believed that God created human beings in the best possible image, bestowing on them a mind enabling them to achieve perfection. He also believed that one's individual character and intellect are determined by one's environment more than genetic factors, predicting that the reformation of existing institutions was sufficient to spread good works all over the world so that all human beings can co-exist in a state of happiness and peace.

Such values and perspective made its best influence on the Arab poets especially the young poets of Apollo Movement. These Romantic Arab poets strongly believed in Shelley, and adopted the same ideas, attitudes, and opinions appeared in his early narrative poems. Different from his popular lyrics, his long narrative poems more profound and impactful and its indulgence into the Eastern 
atmosphere and this was suited to their renewed revolutionary thinking

\section{The English Romantic Movement}

The Romantic Movement arose as a reaction against the cruel world which grim his teeth as the Industrial Age began. It was a time of bloody revolutions appearing in France and America. Poetry as usual came to play his role to heal the injured souls and shocked minds. Shelly's poetry presented to deliver the concepts of freedom and peaceful spirit during a bloody and angry atmosphere in the eighteenth century.

As a literary and artistic movement, Romanticism occurred as a radical reaction to its predecessor Classicism. In its core, Romanticism rejected the ideals of the Classic epoch, which in literature were represented by the influence of ancient Greek and Roman texts. As an artistic and social phenomena, Classicism praised simplicity, rationality or reason, discipline, and the ideals of strict proportion and balance. Meanwhile, the main genres that Classicism focused on were ones from the ancient Greek reality as well, namely, Greek tragedy and comedy along with the genre of ode in poetry. However, Romanticism denied the Classicist idea of a reason, proving that one can understand reality through feeling or irrationality rather than logic and reason. Romanticism emerged in German. Shaped by the philosophical thought of Friedrich Schlegel, early Romanticism was influenced by Pietism, the Enlightenment, Weimar Classicism, and Sturm and Drang, all of which opposed the traditional Classicist ideas (Seyhan 7). As for the historical reality, Romanticism was an age of revolutions, the American and French ones, which changed the direction of world history.

The values of Romanticism based on the restoration of wellforgotten ideas and literary traditions. Romanticism promoted imagination as the only creative power, which allows humankind to change the world by imagining the better one in their heads. The second value is nature, which has a healing power and stands against civilization, considered artificial to humans. The third value is symbolism and myths that led to the revival of "fairy tales, troubadour songs, literature of the European Middle Ages and of ancient India ... Dante, Boccaccio, Cervantes, Calderon, and Shakespeare" (Seyhan 13). Apart from imagination and nature, Romantics emphasized the dominance of feelings and intuition as a leading way for perceiving and analyzing reality. Therefore, art was internalized because literature no longer had to 'mimic' the reality 
around but rather express the artist's internal understanding of the world around and their feelings.

Poetry was the main literary domain, revolutionized the most. The variety of Romantic poetic forms included sonnets, lyric poems, and elegies. Sonnets became popular again, stemming from the renewed Shakespearean and Petrarchan tradition. Sonnets mostly focused on the exploration of romantic relationships and often presented the tragic stories of two lovers. Lyric poetry or lyric poems were the dominant genre, presented mostly as a depiction of nature or beautiful images rather than a narration of a story. Odes, however, focused on the admiration of a supernatural creature, while elegies were a poem that expressed one's lamentation caused by the death of their loved one. All poetic genres were expressed in the oeuvre of the following Romantic poets: William Wordsworth, Samuel Taylor Coleridge, John Keats, Percy Shelly, Mary Robinson, and Charlotte Smith. As for the technical means, Romantic poets introduced the concept of a romantic hero and created a vivid symbolic language, mostly focusing on the surreal as a part of one's imagination. The revolutionary concept of a Romantic hero, for instance, Prometheus in Prometheus Unbound by Shelly or Faust in the same-named epic, were the main characters who reflected on the society, considered revolution and fought against fate, yet often turning into prototypes for further literary works. Another revolutionary concept was the usage of dialects and colloquialisms to make characters bright and real as the oeuvre of Emily Bronte and William Wordsworth suggests, hence rejecting the class division. Therefore, poetry reflected revolution both in its form and the heroes it created.

First-generation poets such as William Wordsworth, Samuel Taylor Coleridge, and Robert Southey put the basic seeds for the revolutionary philosophy the movement is up to. Lyrical Ballads (1798) appeared to reflect all the principles of the time. In his iconic poem, "Lines Written in Early Spring", Wordsworth symbolizes simply the French Revolution and the promising future about to rise in the title of the poem, "spring". He emphasizes on that this spring is in its beginning, "early". Wordsworth states the violence that came out of the French Revolution when he says, "What man has made of man" (stanza 2). He surely refers to the massacres committed during the French Revolution when humanity was on the way to break restrictions of tyrant.

Some critics even extremely assert on the psychological part of the Romantic Movement that it represents a kind of refusal of the 
patriarchal authority lies in the monarchical and religious system of that time. Romantic poets revolted against the father symbol in the society whether this father is the king or the Pope. This figure is destroyed in their poems literary or symbolically. Haigwood describes this struggle of the Romantic poets against authorial idols of their time as an "Oedipal struggle". He interprets this struggle to "ultimately a battle between fathers and sons" (470). Their adherence to Nature is interpreted some times as a biased preference to the mother part than the father part that represent authority and tyranny.

\section{Shelley and Romanticism}

Percey Bysshe Shelley is known not only as a romantic poet but a social and political revolutionist of the nineteenth century whose activities are primarily associated with Ireland. Born in 1792 in Broadbridge Heath, West Sussex, England, Shelley grew up as a representative of the upper-middle class. The future poet later entered Eton college but faced expulsion due to the radical pamphlets which the young poet wrote. For instance, one of them is called The Necessity of Atheism, in which Shelley exposed his anti-monarchical and anti-war ideals, which England held regarding the position of Ireland in the eighteenth century. Though written anonymously, the pamphlet led to expulsion. To understand the revolutionary ideas embodied in the poetry of Percy Bysshe Shelley, one should have a profound understanding of world affairs in the nineteenth century. By the time of the French Revolution in 1819, Europe was a union of monarchical states often remaining in a state of war (Hill 165-166). The beginning of the $19^{\text {th }}$ century showed that Europe withdrew from the Enlightenment ideals, embracing capitalism as an economic system, the result of the Industrial Revolution, which happened earlier in the $18^{\text {th }}$ century. As for the native land of Shelley, England was at war with Ireland, which had the status of an English colony and struggled to reach freedom from the oppressor. Therefore, Ireland turned into a perfect platform for Shelley's revolutionist ideas and an object for his romantic poetry.

The political and literary ideas of Shelly intertwined, both representing the principles of Romanticism as a cultural and social movement. As a representative of Romanticism in literature, Shelley was a part of the group, uniting other Romantic poets such as William Wordsworth, Leigh Hunt, and Thomas Love Peacock. The poets believed in the need for renewing the Enlightenment ideals. Therefore, in their poetry, Romantics promoted the power and the value of an individual, the beauty of nature, equality, and individual 
freedom as well as atheism. Considered radical and continuously suppressed by the English regime, the ideals of Romanticism defended the freedom of Ireland as an independent colony with a separate nation and unique culture, promoted social inequality and democratic principles in contrast to a traditionalist, monarchical, and extremely religious England with a growing economic and social class disparity. Therefore, Shelley was among the first European democrats promoting an 'ideal' government.

Shelley is a poet of the age of the Revolution. Known as a revolutionary of modern democracy and social equality, Shelley used his poetry as a weapon against pro-monarchical tyrants. For shelly, revolution is not only connected to the political atmosphere of the nineteenth century, revolution is connected more to the revolutionary spirit he got. A talent of a poet with "passion for reforming the world"(299) went side by side with an excessive lyrical ability.

\section{The Arab Romanticism:}

The Arabic Romantic Movement comes into two waves: Poets of AlDiwan and Apollo movements. These romantic Movements contain mainly Egyptian poets: Abdul Rahman Shukri (1886-1958), Abdel Qadir Al-Mazini (1889- 19 १), and Abass Al-Akkad (1889-1964) who belong to Al-Diwan while other poets like: Ahmad Zeki Abu Shadi (1900 - 1 19 Y ) and the other Egyptian poet Ali Mahmoud Taha (1901-1949) follow them later to Apollo. Abu Shadi and his fellow poets came completely influenced by the after Al-Diwan and AlMahgar poets who raised the slogans of emotion and imagination in poetry keeping the traditional, rhymed form of Arabic poetry. These Romantic poets see that Shelley presents different poetic images and also find "the happiest moments of the best minds" in his writings (Kholousi 29).

As for the poets of Al-Diwan School, who had the succeeded in theorizing a new critical approach, on which the underpinnings of European critical theories relied, their critical opinions were aired in the literary world and their poems were at last freed from the fetters of the traditional poem, from its content and form. While the two different schools were quarreling, Al-Diwan School and the Revival School (jama'at al-Ihyaa), a group of poets took a new emotional turn, i.e. adopted an approach that was different from the conventional approach to poetry. These poets gathered around Ahmed Zaki Abu Shadi, who had returned from England, influenced by romantic poetry and its emotional environment, subjective nature and humanist ideology. 


\section{دورية علمية محكمةـ كلية الآداب- جامعة أسوان أبريل 9 ب ب}

The political, intellectual, social and economic conditions in Egypt, kindled these poets' intense feelings and stimulated them to romantic and subjective poetry that surpasses that composed by the poets of the Al-Diwan School who suffered terribly from loneliness. This occurred after Shukri had lived in seclusion and Mazni turned to journalism.

Indeed, Egypt was faced with an unprecedented adversity in the third decade of the twentieth century when Apollo School emerged, and the English tightened their grip on Egypt. The royal palace imposed their tyranny over the Egyptian people while it protected the English from any harm and prevented anything that could harm their relations with each other.

As a result, the Constitution was suspended, the elections stopped, and the conflict between parties intensified. Patriots were persecuted under the Ministry of Muhammad in particular. Furthermore, newspapers and magazines were banned. When Ismail Sedki succeeded his predecessor Mohamed Mahmoud, he continued his enmity towards the Egyptian people and his loyalty to the palace. Thus, life in Egypt continued to boil, but on the other hand it offered a fertile soil which was very receptive to desperate people's feelings of sorrow, warm emotions, and their heavy hearts. Their poems ended with an expression of a sense of hopelessness, a sense of loss, and an aspiration for a world where values and virtues prevail. They may have suffered from the scourge of the century which was previously mentioned. In fact, most of the poems composed by Shukri, al-Aqqad, and al-Mazni, which were influenced by this romantic view, enormously influenced the poets of the Apollo School.

The book of Diwan (Divan) was printed in 1921. Although, the roads they went down were not winding as those gone down by the poets of Al-Diwan School, they were paved with the poetry and criticism previously mentioned. The poets of the Apollo School pursued and developed the approach adopted by the poets of AlDiwan School as well as Al-Mahjar School, expanding its aspects, until they revealed a clear-cut romantic tendency.

This poetic movement was coupled with social and mental liberation as is the case with women's liberation. Women were provided with all means to participate in the literary, social and intellectual worlds. Those who came back from Europe contributed to freeing people from the fetters of ignorance. They meditated on life as a whole and checked accuracy. They also attempted to show the 
insights they gained from literary schools, critical approaches and types of poetry. All this paved the way for the liberation of literature and poetry, and for the new meditation on its functions and approaches.

Abu Shadi occupied a leading and crucial role in this liberation, and consequently carried a special burden of responsibility. He supported some poets who believed in what he believed in and aspired just like him for a world in which man is freed from the fetters of ignorance and his hopes are fulfilled. They all failed to achieve this goal which they pursued. Consequently, they resorted to nature so that their burdens could be lightened by the leafy shades of trees and wide horizons. Others sought to have relationships with women, whose kindness was consolation to them. Such relationships with women quenched the thirst of their hearts which burned by love.

Furthermore, their philosophical opinions and reflections did not enable them to achieve their aspirations. Therefore, they followed the same approach adopted by romantic European poets, thereby achieving a more profound change than that made by Al-Diwan School. Thus, the Apollo School prospered in 1932. In the same year its magazine was published and named after the same name.

One look at the titles of their poems on nature, love, philosophical meditation, their poetry collections is sufficient to confirm their inclination for romanticism. Abu Shadi composed poetry collections entitled ash-Shu'lah, (The Torch) and Fawq al'ubab (On The Waves), Min Waraa al-Ghamam (Behind the Gloom) by Ibrahim Nagi, al-Malah al-Ta'ih (The Lost Navigator) by Ali Mahmoud Taha, al-Alhan ad-Dai'ah (The List Melodies) by Hassan as-Sirafi, and al-Anfas al-Muhtariqah (The Burning Breathes) by Mahmoud Abu al-Wafa (Mandour 70-77).

There are some topics around which the poems composed by these poets revolve: sad melodies, desperate looks, meditating on life and the universe, crying over lost love. These topics reflect their characters and their aspirations which were in vain. Although the approach used by these poets in their reflexive and emotional poems reflects clearly their escape from reality, it represents a revolution in the content and form of the traditional poem. For romanticism in itself is not only an escape from life events, but also a rebellion against it, literature and poetry in particular. The ideas of their poems, which foresaw this rebellion, were inspired by their emotions and philosophical reflection. 
Their poems were clad in a new style but it was not groundbreaking and did not keep pace with the modern life as supposed to be. They had a tendency towards romantic subjective poetry in its English version which influenced their poetic products. The fact that their poetic products were enormously influenced by romanticism does not mean that they secluded themselves from society and its tribulations. However, they longed for liberation, justice and sound democratic life despite all of these circumstances. These meanings were reflected in their poems even if they give an impression of sorrow, hopelessness, distant dreams, fear of the unknown fate, defeat and loneliness.

\section{Shelley and the Romantic Arab Poets}

As an idealist of a new democratic order, Shelley introduced the main social and cultural principles of Romanticism. Defending social equality, non-industrialization, anti-monarchy, and individualism, Shelley portrayed his revolutionary ideals in his pamphlets and poetry, Shelley's translated writings inspired Arabic poem scholars in the Apollo school of poetry. The Apollo project by the romantic Arab poets is known for creating a platform for the Free verse movement. The institution, which is a creation of Ahmad Zaki Abu Shadi, intended to revive Arabic poetry in the land. Apollo was a "god of sun, poetry, music, and prophecy" and the guide of the founded group (Fakhreddine 24). Notably, Apollo poetry depicts a Romantic era in the twentieth century that saw the transition towards modernism. For that, the school translated English romantic poetry into the Arabian language, creating platforms through which the literature scholars based their writing styles and ideas (Fakhreddine 24). Percy Bysshe Shelley won a significant favor among Arab poets, and his works appeared in many publications, especially Apollo. A broad spectrum of Arab poets copied, emulated, and plagiarized Shelley's poems to gain his perspective of brilliance within the domain.

The personality of Shelley was fascinating to the Arab Poets. According to Abdel-Hai, the dual nature of Shelley created a platform through which the Arabs worshipped him. For instance, the poem 'Brooke' gave an insight into the dual personality of the poet who created a mentality of two worlds where one, the reality, comprised humanity and hope, whereas the other was a fantasy. The first world was moral and inspiring, while a different version had no ethical boundary (Abdel-Hai 72). Textbooks used to teach young Arab poets contained the works of Shelley (Abdel-Hai 74). Scholars such as Abu Shadi acknowledge that Shelley intended to make people 
happy by providing a platform through which people could create visions of a perfect life. The poet's ability to transpire to realms unknown to human beings inspired the novelty of many Arabic poets.

The Arab Romantics claim that they know "real Shelley" who has a free voice invested later in politics and revolution matters and helped in portraying his image as a revolutionary prophet. Metaphysically, Arab Romantics saw Shelley's passion for life more than his passion for political issues. The famous magazine, Apollo along with other magazines appeared in the beginning of the twentieth century played a big role in presenting Shelley to the Arabic literary society.

Although the Romantic Arab poets appreciated most of the Romantic English poets such as: Coleridge, Wordsworth, Byron, and Keats, Shelly held a special position among the Romantic pioneers. Most critics see the influence of Shelley in the revolutionary spirit which adopted by the Arab Romantic poets. However, the truth is that the romantics in Arabic and English worlds share a higher concept of freedom and dream in Shelley's poetry. It can be said that Shelley transformed the mood of poetry of the Arabic Romantic Movement in general.

This critical poetic trend was accompanied by social and intellectual emancipation, which was formed in the call to the liberation of the woman, and opened all avenues that allow them to perform literary, social and intellectual life. For the returnees from Europe, minds have been freed from the abundant adhesion to traditions. The new look gained depth and sought accuracy, and try to benefit from the new mood in the literature, methods of criticism and the conduct of poetry. This may lead to a call for liberation of literature and poetry, and having a new look at its function in forming a new thought.

It is not only the movement of translation of his poetry that had been heavily promoted Shelley, but also his real influence by and on the Egyptian, Arabic, and Islamic culture. Shelley is the writer of the "Ozymandias" with its strong reference to the Old Egyptian culture: "And on the pedestal, these words appear:/My name is Ozymandias, King of Kings" (6-8). Also, his poem, "The Revolt of Islam", is an epic long poem that discusses the French Revolution that went through many sensitive religious issues with rare daring. Thus, it is obvious that Shelley was not isolated from the eastern culture. Likewise, he was observed very well by the Arab poets in their new spirit in the twentieth century. However, Shelley's 
reference to many Eastern and Arabic places and accidents related to the this ancient culture, this influence on Shelley is still limited. It is Shelley's poetry which adds much more to the Arabic culture in the beginning of the twentieth century.

In Shelley, the Arab Romantics found the renovation they aspired for. His ego as a poet gave them satisfaction after years of neglecting and underestimation. The Golden Treasury which contains poems of Wordsworth, Coleridge, Shelley and other Romantic poets was a real treasure for the Arab poets as most of its poems are translated into Arabic. Among these great names, Shelley could attract most of the attention as his young, rebellious spirit suits their raging aspiration for liberation, imagination, and even chaos.

Abu Shadi used to come to this role and carried his banner, and took the responsibilities for his generation. Next to him is a group of young poets, who believe in what he believes in. They dreamed of a world that is liberated from all limitations, dreams are fulfilled, and hopes and aspirations all achieved. They became merciful to nature with its vast shadows and broad horizons. Most of them see Nature is the power whereas some of them sought the woman seeking love, emotions, and peace. This formula is presented intensively in Shelly's early poetry as it reveals an innocent aspiration for liberation, beauty, and love. Shelley in his early poetry represented a free spirit of incautious poet who is not burdened yet by the loads of chauvinism and saving the world.

Shelley in his early long poems is different from Shelley in his later short lyrical poems. In his early poems, he was optimistic while his later lyrics are sad and cynical. His early long poems are presented for the humanity in a trial to change the future of mankind while his later poems represent Shelley as a pessimistic, melancholic poet. "There is no contradiction between them. He was Optimistic about the future of the human race, pessimistic (almost always) about his own future as an individual" (Ian 98). His late lyrics were more famous and took most of attention of the English and Arab Romantics as it represents their natural tendency to escape in their gloomy world. This gloomy atmosphere is clear in his famous poem, "A Lament":

O world! O life! O time!

On whose last steps I climb,

Trembling at that where I had stood before;

When will return the glory of your prime?

No more-Oh, never more! (1-4) 


\section{دورية علمية محكمةـ كلية الآداب- جامعة أسوان أبريل 9 ب ب}

Shelley's long poems were not celebrated in the same way of his short lyrics whether from readers or critics. His short poems register his personal and intimate emotions of love, sadness, boredom and depression. These feelings are seen obviously in his short 8-lines lyric, "Music when Soft Voices Die". It is a poem about music, odours, loss, mourning, love, hope, and faith:

Music, when soft voices die,

Vibrates in the memory-

Odours, when sweet violets sicken,

Live within the sense they quicken. (1-4)

\section{Shelley's longer Poems}

Shelley's early long poems are more open to the external world. His involvement in his inner world has not begun yet. These long poem did not receive the attention they deserve, although, they are very revealing about the great experienced poet that about to appear a few years later. His long poems are more philosophical, sophisticated, and speculative. Enani revived the English Romantic movement and its leading poets in his famous book, نصوص من الثعر القصصي الرومانسي" [Texts from the English Romantic Narrative Poetry: Coleridge - Keats - Shelley -Tennyson]. In his book, Enani translated some long narrative poems for some pioneers of the English Romanticism. Shelley is one of these Romantic figures whose early long poems did not receive the attention they deserve. In this translation along with his introduction about Shelley's life, Enani sheds light on an ignored part of Shelley's poetic life when he wrote his philosophy in those early long narrative poems.

Enani's translation of "Queen Mab" and "Alastor" takes attention back to Shelley's poetry in a new perspective as he sees that Shelley should not be only regarded as the rebellious poet with the popular short lyrics. Enani's effort to take the gleam to Shelley's early obscure years, in fact, led to a new interpretation and appreciation to Shelley's early long narrative poems. We are introduced to meet a different Shelley from the poet we used to meet in the academic journals of the past years which focused mainly on the radical revolutionary poet of the short lyrics. This perspective was one-sided and therefore misleading as it prevents us from seeing the real, complete picture of Shelley. In the shadows of Enani's translation, the following part of this research is dedicated to present a new interpretation of Shelley's longer poem, especially "Queen Mab" and "Alastor". This new interpretation tries to reveal some 
early thoughtful influences which led to the mature famous poet that appears later.

Shelley's early poems are characterized by unlimited imagination that emanates from his the myths and Greek superstitions. This absorption in Hellenism along with fascination in the antique Eastern cultures provide Shelley's longer poem with this mystical, philosophical, thoughtful perspective. One of these early long narrative poems is "Queen Mab" which is written in 1918. The poem came as a cry in the battle against the monarchy institutions and all the shapes of tyranny all over the world, whether it was religious or political. The spirit of the French Revolution haunted this poem and reflected obviously "his distrust of institutionalism" (Baker 514). Shelley's serious foray into poetic artistry demonstrates his deep fascination with the Eastern trilogies written by Walter Savage Landor in epic form, typical of the Gothic genre. Unable to settle on a specific format for his poem, Shelley took Landor's work as a model, starting his poem with a replication of Landor's approach:

How wonderful is Death,

Death and his brother Sleep!

One, pale as yonder waning moon

With lips of lurid blue:

The other, rosy as the morn

When throned on ocean's wave

It blushes o'er the world:

Yet both so passing wonderful! (1-8)

The first canto is dominated by the sense of wonder one feel when reading a romantic fantasy. In the second canto Mab takes Ianthe to her castle to survey the world as it rotates:

Above, below, around,

The circling systems formed

A wilderness of harmony:

Each with undeviating aim,

In eloquent silence, through the depths space

Pursued its wondrous way. (77-82)

In the third canto Shelley describes his vision of present day reality: he depicts a king surrounded by a circle of flatters. Safe in the presence of the guards protecting them, the men inside the palace are enjoying life's delights, while outside the gates we see the suffering of those who are accustomed to the evils of power. If only 
the mind were to awaken, absolute monarchy would vanish. Shelley paints his vision as follows:

Power, like a desolating pestilence,

Pollutes whate'er it touches; and obedience,

Bane of all genius, virtue, freedom, truth,

Makes slaves of men, and, of the human frame,

A mechanized automaton. (176-180)

According to Shelley, blind obedience to the king's orders implies that the oppressed "fashion the sword that strikes the state of peace they are entitled to". This curious phrase was borrowed from Thomson, whose influence is equally felt as that of Landor.

In the fourth canto Shelley attacks war, beginning with the preamble that the calm of a winter's night can be shattered by the cry of war: $\ldots$ the jar

Frequent and frightful of the bursting bomb;

The falling beam, the shriek, the groan, the shout,

The ceaseless clangour, and the rush of men

Inebriate with rage. (41-5)

Shelley believed that war does not erupt because humanity is generally evil; it is caused by the conspiracies of kings and those in power whose interests lie in igniting warfare:

'War is the statesman's game, the priest's delight,

The lawyer's jest, the hired assassin's trade,

What enrages Shelley the most are the mechanisms enabling the ruling systems to perpetuate themselves:

Then grave and hoary-headed hypocrites

Without a hope, a passion, or a love

Who, through a life of luxury and lies,

Have crept by flattery to the seats of power,

Support the system whence their honours flow. (203-207)

According to Shelley, no blame should be laid on the wretched whose toil is paid for by the tyrant. Tyrants manipulate religion to deceitfully compel these innocents, from early youth, to obey for fear of flouting divine orders. In this sense, heaven is viewed as the promised reward of submission while hellfire is the final destination of those who rebel. He vividly describes the means by which priests deceive simple folk before moving on to the evil of commerce, described as follows: 
Hence commerce springs: the venal interchange

Of all that human art or nature yield;

Which wealth should purchase not, but want demand,

And natural kindness hasten to supply. ( $238-241)$

Shelley is implying here that the notion of 'natural kindness'

proposed by Godwin is not necessarily beneficial in all cases: he

himself was a victim of Godwin's insatiable need for money:

Spirit of Nature! Here!

In this interminable wilderness

Of worlds, at whose immensity

Even soaring fancy staggers

Here is thy fitting temple,

Yet, not the lightest leaf

That quivers to the passing breeze

Is less instinct with thee;

Yet not the meanest worm

That lurks in graves and fattens on the dead

Less shares they eternal breath. (264 -274)

Put concisely, Shelley is saying that the spirit of Nature abounds in all eras of the vast history of existence. The symmetrical form of this spirit is known as "the spirit of the universe" or "the supreme spirit of the world', referred to in James Thomson's Seasons, Mark Akenside's The Pleasures of Imagination, and Edward Young's Night Thoughts. Shelley similarly drew on the Wordsworthian concept of the divine spirit throbbing at the heart of existence as well as the eighteenth century concept of spiritual enquiry in order to fill the voids found in the material world. While Shelley's portrayal of the soul was infused with greater positive energy, he does not reveal whether or not the soul possesses free will. Shelley makes the following observation on the smallest life forms:

I tell thee that those viewless beings,

Whose mansion is the smallest particle

Of the impassive atmosphere,

Think, feel and live like man;

That their affections and antipathies,

Like his, produce the laws

Ruling their moral state;

And the minutest throb

That through their frame diffuses

The slightest, faintest motion,

Is fixed and indispensable 


\section{دورية علمية محكمةـ كلية الآداب- جامعة أسوان أبريل 9 ب ب}

As the majestic laws

That rule yon rolling orbs. (231 -243)

This ambitious work, articulating in stirring language Shelley's revolutionary vision, can be read today by youth with the same rebellious spirit. After Napoleon's defeat and Europe opened its doors once again to visitors, the world around Shelley was changing rapidly. At home, he was unhappy in his marriage, for Harriet was not the person he had begun life with. He often told Hogg that he felt prematurely old due to his dissatisfaction with his personal life and his helplessness in changing the world for the better. The works he wrote after "Queen Mab" reflect that Shelley was on the verge of a nervous breakdown, despite not knowing the nature of his mental affliction.

In June 1814 Harriet departed for Bath, expecting Shelley to join her there after he had raised some funds for Godwin. The poet had been invited to reside in Godwin's house where he met the philosopher's daughter, Mary. Shelley fell madly in love with Mary to the extent that Peacock, a highly reliable source, reported that he had never seen such sudden passion. Among the English travellers flocking to France to celebrate Napoleon's defeat were Shelley and Mary Godwin, along with her sister, Jean Clairmont, who ran away together. They spent several months in war-torn France before returning to England where Godwin refused to receive them. To escape creditors and moneylenders, the trio moved from hotel to hotel until in 1815 the death of Shelley's grandfather put an end to his financial distress. With a comfortable income of one thousand pounds per year, Shelley and Mary settled in Windsor.

Before we turn our attention to "Alastor", it is worthy to note that Shelley was closely affiliated with both the great Romantic poets such as Wordsworth, Coleridge, and Landor as well as their predecessors such as John Dryden, Thomas Grey, and William Collins. Even as he read the works of these influential poets, Shelley was aware that not all of them had remained true to their original ideals, especially Wordsworth, whose revolutionary zeal at the beginning of his artistic path was replaced by conservative leanings and distance from his early outpourings. That said, Wordsworth's influence remains evident in Shelley's poetry despite turning his back on revolutionary fervor, causing Shelley to dedicate the following to Wordsworth:

Poet of nature, thou hast wept to know

That things depart which never may return; 
Childhood and youth, friendship and love's first glow Have fled like sweet dreams, leaving thee to mourn.

These common woes I feel. One loss is mine

Which thou to feel'st, yet I alone deplore.

Thou wert as a lone star, whose light did shine

On some frail bark in winter's midnight roar;

Thou hast like to a rock-built refuge stood

Above the blind and battling multitude;

In honoured poverty thy voice did weave

Songs consecrate to truth and liberty

Deserting these, thou leavest me to grieve,

Thus have been, that thou shouldst cease to be.

Spending the summer of 1816 with Lord Byron on the shores of Lake Geneva, Shelley wrote two philosophical poems, "Hymn to Intellectual Beauty and Mont Blanc", that reveal the extent to which he was inspired by Wordsworth.

Immediately after Harriet committed suicide in 1816, Shelley and Mary's marriage took place. However, custody of his two children by Harriet was denied him, a crushing blow to Shelley that left a sense of loss in many of his works. While living in Bishopsgate on the Thames with his new wife, Shelley wrote some of his most beautiful verse. However, the demands of creditors, failing health, and a sense of being 'hated' by the society drove the couple back to Italy in 1818, where the poet engaged in pleasant pastimes with his friend, Lord Byron.

The summer of 1819 to 1820 saw Shelley create several masterpieces that were translated into Arabic: Prometheus Unbound, "Ode to the West Wind", "The Masque of Anarchy", "The Cenci", "The Cloud", "The Witch of Atlas", and "Ode to Liberty".

"Alastor", written in 1815 and his second major work, propelled Shelley to fame, and assured his poetic path. Unlike the reformist and intellectual themes of "Queen Mab", "Alastor" explores humanistic themes and yearnings while raising many questions without presenting any answers. This work illustrates the dramatic shift experienced by the poet; saving the world was no longer his mission as his wife, whom he regarded as a soul mate, inspired him to focus on subjective imaginings of humanity. Despite safeguarding his intellectual vision, Shelley's extreme sensitivity drove his poetic imagination to burst forth like a torrent.

Some scholars believe that the contradictions within the poet were related to the opposing concepts of self-love and altruism. In 
other words, "Queen Mab" portrays a selfless concern for others (in terms of improving their lot rather than his own) while "Alastor" emphasizes subjective happiness or self-love. According to late nineteenth century critics, Shelley works can be divided into two distinct parts: lyric poetry voicing the poet's thoughts, a genre that was popular with readers, most of which has been translated into Arabic; and, reformist works that offended his audience. The opposing themes reflected in Shelley's works (humanitarianism versus rationalism; selfishness versus philanthropy; and those who brag versus true reformists) can be interpreted through each individual's perception.

The hero of "Alastor" is an unnamed, intellectually gifted but innocent youth, untainted by worldly concerns. As a voracious reader of great literary pieces since his early years, Shelley reached his maturity equipped with the valuable ideas absorbed from his chosen authors. His hero poet in "Alastor" at first devotes himself to the delights of Nature's beauties; however, he abandons his pursuit of ideal beauty in Nature to seeking the ideal feminine soul mate with a purity of mind to equal his own. When his search proves futile, the poet falls into an early grave. Despite the gifts Shelley bestows on this poet, he never actually achieves his quest; instead, he declines at an astonishing speed. Shelley deliberately chooses not to give his hero a name not only to disassociate him from the world of material gain so detrimental to true purity, but also to preserve the pristine beauty of the setting.

Shelley's initial inspiration, in keeping with Milton's style, swiftly changes into open worship of Nature where the poet is depicted lying in Nature's embrace, reminiscent of Wordsworth eulogies despite the desolate gloom. We notice that from Line 50 to 57 there are two nouns in each of these lines, giving us a total 16 nouns, 14 of which are preceded by an appropriate adjective. Shelley saturates his verse with excessive details, which, in stylistic terms, indicates one of the pitfalls of being an amateur. This saturation of detail, moreover, presents difficulties for the translator when tackling the problem of rhyme.

The hero in this poem revels in the wonders of Nature, to which he remains a worshipper until Lines 151 - 154:

He dreamed a veilèd maid

Sate near him, talking in low solemn tones.

Her voice was like the voice of his own soul

Heard in the calm of thought; 


\section{دورية علمية محكمةـ كلية الآداب- جامعة أسوان أبريل 9 ب ب}

The above articulates his Platonian belief that one's soul mate is a completion of self. It may take years of searching to find this soul mate as the essence of the soul is hidden.

His strong heart sunk and sickened with excess

Of love...

On waking from his dream the poet discovers that the delights of Nature now seem dull. He is obsessed with the vision/phantom he saw in his dream. He spends the rest of the poem wandering from east to west in search of the soul mate he glimpsed until his withered body is transformed into a spectre.

The legend of Ulysses and the vagrant Jew often featured in the works of Shelley and other Romantic poets, as we can see in the final act of Wordsworth's play The Borderers and Coleridge's "The Rhyme of the Ancient Mariner" who wanders from place to place to tell his tale.

During his wanderings, the poet in "Alastor" reaches the Carmanian shore in Persia where he sees an abandoned sailing boat. As he passively sits in the boat, the waves toss him hither and thither, a recurring image in the works of Shelley that symbolizes the perilous relationship between boats and human existence, mirroring the conflict between life and death. Shelley's fascination with sailing boats on treacherous waters invigorated his spirit, despite his poor swimming ability. According to Desmond King-Hele in Shelley: His Thought and Work:

Small sailing boats are the exact embodiment of Shelley's personality. He often gave the impression of a skiff gliding precariously over the ocean of life, struggling against the current after having placed his ideals inside a box that the swirling waves could not permeate. This reinforces Shelley's reliance on the image of a boat floating on the river's surface, symbolizing the journey of the spirit on earth while the turbulent water reflects poetical broodings. (58-59)

Once the poet embarks on the boat, we note that the poetical language in this work starts to flow more languidly. Surviving a sudden and violent storm, the boat is pulled along, as the midnight moon appears, under the Caucasian cliffs, the Poet catches sight of a subterranean river whose whirlpool takes it down to the bowels of the earth. The whirlpool touches the tip of the boat without sucking it in; 
instead, the boat flows towards another rivulet gently meandering towards a winding forest, and the Poet is saved from death.

According to ancient folklore, rivers flowing beneath the surface of the earth were a miraculous thing. Contemporary critics, however, claim that this sense of wonder is intentionally employed for the sake of filling the need to contemplate the majesty of Nature. Landor's epic poetry, for example, abounds with subterranean caves and rivers, as evident in Coleridge's yet unpublished work, "Kubla Khan".

"Alastor" showcases Shelley's gift in describing the beauties and wonders of Nature, which despite Thomson's influence, form the poet's independent vision whose imagery draws from Shelley's personal experience of the English countryside:

Tremulous and pale. Like restless serpents, clothed In rainbow and in fire, the parasites,

Starred with ten thousand blossoms, flow around The grey trunks, and, as gamesome infants' eyes, With gentle meanings, and most innocent wiles, Fold their beams round the hearts of those that love, These twine their tendrils with the wedded boughs Uniting their close union; $\quad(438-445)$

According to Matthews, we notice the following:

Although his syntactic usage could be improved upon, in addition to reducing the descriptive adjectives, Shelley's work is not that of a traditional Nature poet. Rather, it represents a unique interpretation that signals an unrivalled rendering of literature devoted to Nature. (86)

Comparing imagery in the works of Keats and Shelley, Richard Harter Fogle notes the use of images positioned on or in still water:

A little space of green expanse, the cove Is closed by meeting banks, whose yellow flowers

For ever gaze on their own drooping eyes, Reflected in the crystal calm. The wave Of the boat's motion marred their pensive task, Which nought but vagrant bird, or wanton wind, Or falling spear-grass, or their own decay

Had e'er disturbed before. $\quad(406-412)$

Many mistakenly assume that the title of "Alastor" or "The Spirit of Solitude" is the actual name of the poet. Peacock explains: 


\section{دورية علمية محكمةـ كلية الآداب- جامعة أسوان أبريل 9 ب ب}

[Shelley] was at a loss for a title, and I proposed that which he adopted: "Alastor"; or, the Spirit of Solitude. The Greek word, (A $\lambda \alpha \delta \tau \omega \rho)$ is an evil genius, ..., though the sense of the two words is somewhat different, as in the ... of Æschylus. The poem treated the spirit of solitude as a spirit of evil. (100)

In the following excerpt from King-Hele's book Shelley: His Thought and Work, the author sheds light on both the significance of the poem and Shelley's own motivations:

From the rhythmic flow of the poem, no one can possibly intuit that the Poet in "Alastor" is responsible for his own decline. On the contrary, risking hunger or even death, the hero should be glorified for embarking on his solitary journey on the boat. Shelley seems to be referring to the dangers of social alienation or the impossible feat of pursuing an idealized embodiment of a woman, two temptations to which he himself was susceptible. It is possible that Shelley wrote this poem in order to exorcise past errors and express his gratitude for being able to avoid such pitfalls by means of self-examination. The poem might also represent Shelley's own story had he succumbed to his fears. As Mary Shelley explains in her Note, after a prominent doctor had informed the poet that he was dying of tuberculosis, Shelley wrote the poem to bury his own tormented spirit and to express his anticipation of death... .(325)

The above commentary seeks to address the Romantic questions underpinning "Alastor". There is no point in approaching any of Shelley's works - whether early or mature - from a logical viewpoint. We should simply accept Bradley's most excellent point that the contradictions and gaps in Shelley's poetry must be embraced without trying to solve or evade them (O'Neill 40). Shelley's poetry is brimming with the variations upon which human life is built.

Finally, it can be concluded that in his poem "Alastor" or "The Spirit of Solitude" (1816), Shelley cautioned idealists such as himself not to forsake the fulfilling human love and social improvement for the desperate search for abstract desires (The Editors of Encyclopaedia Britannica). In the exposition, he describes the journey of an idealist who was searching for perfect love. 
Eventually, he succumbed to a state of loneliness. The poem creates a scenery in which the narrator is away from the action and exercises self-centered seclusion. That said, Alastor had a significant impact on the poet's career.

"Alastor" creates a platform for Shelley to explore his ideologies while ignoring the conventional rules binding the poetry universe. According to Quillin, Jean De Palacio describes "Alastor" as the poem of a void and vacant world, which is more visual than musical (3). Most sonnets are in tandem with the music, but Shelley takes on another approach. According to Quillin, unlike his previous works such as "Epipsychidion, Prometheus Unbound and the lyrics to Jane Williams," which are musical, "Alastor" does not adhere to the musical poetry code (3). The dichotomy over music in the poem illustrates the poet's shifting perspectives on music. Additionally, it shows his interest in career growth.

The theme, 'one voice,' presents an argument regarding the poem. According to Stampone, the 'one voice' demystifies many scholars for Shelley's ability to project several personalities through one voice (1). In the poem, it is difficult to assert to whom the voice belonged to. However, it is arguable that it belonged to neither the ethereal maid nor the wind as the syntax and structure used reveal that the voice belonged to an individual. In the exposition, it is a person's synecdoche. The poetic construct of 'one voice' perspective of Shelley in "Alastor" marks the beginning of maturity in his career.

Additionally, "Alastor" sets the pace for the ensuing works of Shelley. According to Coffey, "Alastor" explores the resonant and physiological aspects of life. Furthermore, it explores the gaps and interstices of ration. Shelley manifests his linear intellectual growth, transitioning from materialism to adopt idealism. His growth overcame the chains of the world and created a new system. Coffey states that Alastor delivers a more intricate and advanced structure than most scholars can decipher. For that, in the later poems, for example, On a Future State (1818-1819), the philosophical radicalism of "Alastor" appears (Coffey). His employment of terms and phrases shows his advancement in the entanglement of different universes to create one overwhelming one. His competence and brilliance continue to puzzle many contemporary Romanticism scholars who use Shelley's poems as a ground to make a compelling insight into romance.

"Queen Mab" and "Alastor" offer a platform through which Shelley criticizes his career. As implied earlier, the world with which 
the poet gazes is abstract. Shelley attempts to picture himself in a path in the pursuit of an ideal world, but he ends his piece with a sorrowful twist of a lonely death. Worthen states that that one rationale for Shelley's inclination to dessert the poem in the very state was because it had an impact on him (129). The philosophy appears in these long narrative poems is an illustration of the tendency of the poet to seek knowledge while ignoring the true happiness of the world.

\section{Conclusion}

The previous analysis which depends mainly on Enani's new translation of Shelley's "Queen Mab" and "Alastor" tries to prove that Shelley's philosophy appears in its most original in his early narrative poems. A philosophy that a combines between his "belief in the power of human love and reason, and faith in the perfectibility and ultimate progress of man." (Xiao-hui 505). Enani's new translation of Shelly's "Queen Mab" and "Alastor" provides a new opportunity to a see a different view of Shelley's poetry. Shelley is not remembered only as a poet of nature lyrics and wild rebellious poems, but also as a philosopher. Enani's translation flows from a well-informed consideration of the personal accidents Shelley went through in the early years of his short life. Hence, this sober translation helps to introduce Shelley plain, pure and free as he appears in his early longer poems, "Queen Mab" and "Alastor".

Shelley did not find fame in his early life. Still, his poetic and literary work inspired a lot of people, including Arabic poets, in the Apollo movement, following his death. "Queen Mab" came as Shelley's first major poem, and in Alastor, Shelley progressed into his poetic style and character that would be seen in his later mature works. In "Queen Mab", Shelley's poetic form lacks the dominating protagonist that became typical of his later "Shelleyan" poems, including Alastor (Blank 87). As such, in "Queen Mab", Shelley expresses his early views that highlight some elements of didacticism. His notes in "Queen Mab" allude to his youthful style as he touches on multiple aspects such as vegetarianism and astronomy. While "Queen Mab" presented an organized and chronologic, "Alastor" highlighted the narrative and dramatic Shelleyan style. Therefore, "Alastor" became an essential introduction to the mature Shelley's mature style featuring a dominant struggling protagonist that conveys an emotional, rather than logical, commitment.

Some influences on Shelley included William Wordsworth, his father-in-law, the philosopher William Wordsworth, Leigh Hunt, and 
his close friend Thomas Love Peacock. As Shelley's poetic style matured, Wordsworth's influence on his character appears in his work. For example, the poet illustrated in his "Alastor" poem related to Shelley's idea of Wordsworth (Blank 87). The poet protagonist in "Alastor" shows elements of originality and poetic selfdetermination. As a result, the Wordsworth figure appears in his work in "Alastor" and other poems as he matures into his style. In "Queen Mab", Shelley started growing into ambiguity, which afterward became a hallmark of exploratory poetry, influenced by close associates such as Peacock (Callaghan, Shelley's Living Artistry 23). As he leaves the youthful style of "Queen Mab", it's the new style that helps him become successful and attain global recognition for his work.

Shelley's poems went ahead to influence late Victorian era poets in the Arab region, especially his works with romantic poetry, including the Apollo movement. In the early twentieth century, as the British colonial rule penetrated the Arab Peninsula, Shelley's work reached Arab poets. For example, according to the bibliography of Arabic translations, Shelley's novels became the most translated in English literature to the Arab language, including Apollo. As a result, Shelley's style in works such as "Alastor" comes evident in the Apollo movement's themes and imagery of romantic poems in the region between 1910 and 1950 (Fakhreddine 24-25). As the Apollo movement constituted Arab poets that mostly draw their influence from western romantics, Shelley became a favorite, leading to various planarization of his work in their literature. Furthermore, as Apollo sort of revived Arabic poetry among young Arab poets, works such as Shelley's became a cornerstone in their rebuilding efforts. 


\section{دورية علمية محكمةـ كلية الآداب- جامعة أسوان أبريل 9 ب ب}

\section{Works Cited}

Abbey, Lloyd. "Shelley's Bridge to Maturity: From 'Alastor' to 'Mont Blanc." Mosaic: A Journal for the Interdisciplinary Study of Literature, vol. 10, no. 4, 1977, pp. 69-84.

Abdel-Hai, M. "Shelley and the Arabs: An Essay in Comparative Literature." Journal of Arabic Literature, vol. 3, 1972, pp. 72-89.

Allen, L. H. "Plagiarism, Sources, and Influences in Shelley's "Alastor." The Modern Language Review, vol. 18, no. 2, 1923, pp. 133-151.

Al-Zubaidi, A. M. K.. "The Dīwān School." Journal of Arabic Literature, vol. 1, 1970, pp. 36-48.

Archer, Jerome W. "Kubla Khan: Queen Mab, II, 4-79; VIII, 70-103, and Alastor, 81-94; 163-172." Studies in Philology, vol. 41, no. 4, 1944, pp. 576-581.

Baker, Carlos. "The Permanent Shelley." The Sewanee Review, vol. 48 , no. 4 , 1940, pp. 512-518.

---, and David Lee Clark. "Literary Sources of Shelley's The Witch of Atlas." PMLA, vol. 56, no. 2, 1941, pp. 472-494.

Bernhardt-Kabisch, Ernest. "The Stone and the Shell: Wordsworth, Cataclysm, and the Myth of Glaucus." Studies in Romanticism, vol. 23, no. 4, 1984, pp. 455-490.

Blank, G. Kim. Wordsworth's Influence On Shelley. 1st ed., Palgrave Macmillan Limited, 1988.

Callaghan, Madeleine. "Shelley and the Ambivalence of Idealism." Keats-Shelley Journal, vol. 64, 2015, pp. 92-104.

---. Shelley's Living Artistry. Liverpool University Press, 2017.

Cauchi, Francesca. "A Rereading of Wordsworth's Presence in Shelley's 'Alastor." Studies in English Literature, 1500-1900, vol. 50, no. 4, 2010, pp. 759-774. 


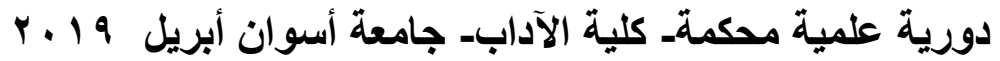

Clarke, George Herbert. "Refocussing Shelley." The Sewanee Review, vol. 33, no. 1, 1925, pp. 88-94

Coffey, Bysshe Inigo. "Wordsworth Circle." Shelley's Alastor and "On a Future State" 48.1 (2017).

DuBois, Arthur E. "Alastor: The Spirit of Solitude." The Journal of English and Germanic Philology, vol. 35, no. 4, 1936, pp. 530-545.

Enani, Muhammad, translator and introducer. Texts from the English Romantic Narrative Poetry: Coleridge - Keats - Shelley Tennyson. The National Center of Translation, 2019.

Fakhreddine, Huda J. "Chapter 1: Introducing Metapoesis in Arabic Poetry." Metapoesis in the Arabic Tradition: From Modernists to Muhdathūn. Leiden: Brill, 2014.

Fogle, Richard Harter. The Imagery of Keats and Shelley. University of North Carolina, 1948.

Fraistat, Neil. "Poetic Quests and Questioning in Shelley's 'Alastor' Collection.” Keats-Shelley Journal, vol. 33, 1984, pp. 161181.

Havens, Raymond D. "Shelley's Alastor." PMLA, vol. 45, no. 4, 1930, pp. 1098-1115.

Ian, Jack. English Literature: 1815-1832. Oxford, 1963.

Jones, Frederick L. "Alastor Foreshadowed in St. Irvyne.” PMLA, vol. 49, no. 3, 1934, pp. 969-971.

---. "The Inconsistency of Shelley's Alastor." ELH, vol. 13, no. 4, 1946, pp. 291-298.

---. “The Shelley Legend.” PMLA, vol. 61, no. 3, 1946, pp. 848-890.

Kholousy, Safaa. Studies in the Comparative Art and Literary Trends. Matba'a Al-Rabeta, 1948.

King-Hele, Desmond. Shelley: His Thought and Work. Palgrave Macmillan UK, 1984. 
Kirchhoff, Frederick. "Shelley's 'Alastor': The Poet Who Refuses to Write Language.” Keats-Shelley Journal, vol. 32, 1983, pp. 108-122.

Matthews, G.M. "Shelley's Lyrics." The Morality of Art, edited by D.W. Jefferson, Routledge and Kegan Paul, 1969, rpt. in Shelley's Poetry and Prose, 1977, pp. 681-94.

Mandur, Muhammed. The Egyptian Poetry after Shawki [ الثعر المصري بعد شوقي . Nahdat Misr Liberary, 1955.

Mueschke, Paul, and Earl L. Griggs. "Wordsworth as the Prototype of the Poet in Shelley's Alastor." PMLA, vol. 49, no. 1, 1934, pp. 229-245.

Murphy, John F. "Time's Tale: The Temporal Poetics of Shelley's "Alastor." Keats-Shelley Journal, vol. 45, 1996, pp. 132-155.

O’Neill, Michael. “A.C. Bradley's Views on Shelley's Poetry and Poetics" Romanticism, vol. 14, 2008, pp. 36-46.

Procter, Harry. Julian and Maddalo: Shelley's early glimpse of Psychotherapy (2012) By Harry and Jane Procter. In Giliberto, M., Dell'Aversano, C. and Velacogna, F. (Eds), PCP and Constructivism: Ways of working, learning and living. Proceedings of the XVIIIth International Congress on Personal Construct Psychology, Venice, 2010. Firenza: Libri/Liberi, (pp XIX - XXIX) Book available from: Scuola di Psicoterapia Costruttivista, http://www.icpitalia.it/scuola/en/home.php

Peacock, Thomas Love. Memoirs of Shelley and Other Essays and Reviews. White Press, 2018.

Quillin, Jessica K. "Chapter 3: "Her Voice was Like the Voice of his Own Music and Silence in "Alastor"; or the Spirit of Solitude." Quillin, Jessica K. Shelley and the Musico-Poetics of Romanticism. Routledge, n.d. wiE_O3345zpAhWQ0eAKHaHWAjgQ6AEwBXoECAsQA $\mathrm{Q} \# \mathrm{v}=$ onepage $\& \mathrm{q}=\mathrm{imp}>$.

Ra'ouf, Gihan. Shelley in the Arabic Literature in Egypt. Dar alMa'aref, 1980. 
Rieder, John. "Description of a Struggle: Shelley's Radicalism on Wordsworth's Terrain.” Boundary 2, vol. 13, no. 2/3, 1985, pp. 267-287.

Rodenbeck, John. "Literary Alexandria." The Massachusetts Review, vol. 42, no. 4, 2001, pp. 524-572.

Scales, Luther L. "The Poet as Miltonic Adam in 'Alastor." KeatsShelley Journal, 21/22, 1972, pp. 126-144.

Stampone, Christopher. "The "one voice" in Percy Shelley's ALASTOR." The Explicator 74.1 (2016): 1-4.

Strickland, Edward. "Transfigured Night: The Visionary Inversions of 'Alastor.'” Keats-Shelley Journal, vol. 33, 1984, pp. 148160.

The Editors of Encyclopaedia Britannica. "Alastor." 18 February 2018. Encyclopadia Britannica. www.britannica.com/topic/Alastor.

Webb, Timothy. "Coleridge and Shelley's Alastor: A Reply." The Review of English Studies, vol. 18, no. 72, 1967, pp. 402-411.

Wier, Marion Clyde, and Raymond D. Havens. "Shelley's 'Alastor' Again." PMLA, vol. 46, no. 3, 1931, pp. 947-951.

Worthen, John. "Chapter 13: "Alastor'queen mab (1815-1816)." The Life of Percy Bysshe Shelley: A Critical Biography. John Wiley \& Sons Ltd, 2019. 124-134.

Xiao-hui, Gong. US-China Foreign Language, July 2015, Vol. 13, No. 7, pp.495-507. 